\title{
PutTing Prosody First — SOME PracticAL SOLUTIONS TO A PERENNIAL PROBLEM: THE INNOVALANGUES PROJECT ${ }^{1}$
}

\author{
DAN FROST \\ Université de Savoie, France \\ dan.frost@univ-savoie.fr \\ FRANCIS PICAVET \\ Institut Polytechnique, Grenoble, France
}

\begin{abstract}
This paper presents some of the difficulties of teaching languages, in particular English, in the context of LSP/LAP ${ }^{2}$ programmes in French universities. The main focus of this paper will be the importance of prosody, especially in English, as an area where these difficulties may be addressed. We will outline the various solutions that are currently being put into place as part of the Innovalangues project, a six-year international language teaching and research project headed by Université Stendhal (Grenoble 3), France. The project has substantial funding from the French Ministry of Higher Education and Research and its mission is to develop innovative tools and measures to help LSP/LAP learners reach B2 on the Common European Framework of Reference for Languages (CEFRL). The languages concerned are English, Italian, Spanish, Chinese, Japanese and possibly French as a foreign language. Initially the project will be focusing on the needs of Grenoble's students, but the objective is to make the tools and resources developed freely available to the wider community. Oral production and reception are at the heart of Innovalangues. We believe, along with many other researchers, that prosody is key to comprehension and to intelligibility (Kjellin 1999a, Kjellin 1999b, Munro and Derwing 2011, Saito 2012), particularly given the important differences between English and French prosody (Delattre 1965; Hirst and Di Cristo 1998; Frost 2011). In this paper, we will present the particular difficulties inherent in teaching English (and other foreign languages) in the context of $\mathrm{ESP} / \mathrm{EAP}^{3}$ in French universities and some of the solutions that we are implementing through this project (Picavet et al., 2012; Picavet et al 2013; Picavet and Frost 2014). These include an e-learning platform for which various tools are being developed, teacher training seminars focusing on prosody and the collection of data for research.
\end{abstract}

\footnotetext{
${ }^{1}$ www.innovalangues.fr

${ }^{2}$ Languages for Specific Purposes / Languages for Academic Purposes.

${ }^{3}$ English for Specific Purposes / English for Academic Purposes.
} 


\section{Introduction}

The fact that all students in tertiary education in France are obliged to study a foreign language, usually English, regardless of the subject in which they major, is perceived in different ways by the different people involved (Taillefer 2002). Regardless of the perceptions of the various actors, the LSP/LAP sector in French universities is extremely important as regards the number of students taught, the number of teaching hours involved and the number of teachers employed on permanent and temporary contracts. However the teaching conditions vary enormously depending on the institution: class sizes are often very large, courses run for 10 to 60 hours per year, resources are sometimes scant and the methodology is often still influenced by the grammartranslation method, with only passing references to communicative approaches, such as task-based learning, the action-oriented approach, etc. The French Ministry of Education and Research has stipulated the levels which it expects learners to achieve in their L2 and L3 at various stages of the education process, and for LSP/LAP learners, this means B2 according to the CEFRL after 3 years at university (Goullier 2007). The reality is somewhat different from this aim however, with oral reception and production skills in particular being closer to A2 or B1 more often than B2 for most students arriving at university in France (Taillefer 2007). As we shall see below, the Innovalangues project is designed to deal with this disconnect.

Since the predominance of the communicative approach in L2 teaching over the last quarter of a century, many authors have decried the lack of attention given to the teaching of pronunciation in the L2 classroom (Scarcella and Oxford 1994; Derwing et al 1998; Derwing and Murray 2005; Gilbert 2010; Baker and Murphy 2011; Henderson et al. 2012). The amount of time dedicated to pronunciation teaching is generally relatively small, particularly in French LSP/LAP classes. When we add to this the fact that phonological transfer is the most noticeable form of L1 interference throughout the life of a language learner (see Major 2008 for a detailed discussion), it is hardly surprising that pronunciation entails many difficulties for French learners.

For the purposes of this article, we are particularly concerned with learners of English for specific and academic purposes (ESP/EAP), and there are vast differences between the French and English phonological systems (as we shall see in the next part). It is perhaps unsurprising therefore, that pronunciation is an area which French teachers of English often shy away from in their everyday practice and that the methodology of teaching pronunciation is also something which is often neglected in French teacher training programmes, which tend to concentrate on texts, grammar and vocabulary acquisition. These differences between the phonological systems of English and French are particularly pronounced when it comes to prosody. This has resulted in a vicious circle by which poor pronunciation, especially in English, is propagated in many learning situations in France and the effects on the production and comprehension of oral English are evident (Henderson et al. 2012). Indeed, a section entitled "phonology" in the national curriculum for teaching English made its first appearance as late as 1985 (Brossard 1995).

In this article, we shall begin by examining the differences between the phonological systems of English and French in a little more detail, particularly regarding prosody. The rest of the paper will be devoted to presenting the Innovalangues project and more 
specifically, some of the proposed solutions which are currently being implemented to improve the oral skills of French LSP/LAP learners in Grenoble and beyond.

\section{English and French prosody}

As we mentioned in the introduction, the vicious circle of poor pronunciation teaching stems only partly from teaching practices and the hugely variable teaching situations in the LSP/LAP sector in French tertiary education. The Innovalangues project, has as its mission to improve the teaching and learning of several languages, but this article will deal mainly with the question of English, which has been the major focus of our work during the initial stages of the project. At the heart of the vicious circle of poor pronunciation teaching in France are some very real differences between French and English; we shall begin this section by outlining some of these differences, and then we go on to outline some of the implications of these differences for teaching.

French and English, despite sharing much of their vocabulary, are extremely different both phonetically and phonologically. This is particularly evident in the domain of prosody. Regarding intonation, the typical English speaker has a fairly large range between the low and high points his or her F0 curve will attain, whereas the range in French is much narrower (see Campione and Véronis 1998 for a comparison of F0 range in five European languages). Although it is of course somewhat artificial to draw a distinction between intonation and stress as the F0 curve is a factor in both, the real issue for French learners of English is stress. In this regard, the two languages differ so greatly that many French speakers find it very difficult to even perceive prominent syllables in English. More importantly, francophone learners of English find it very hard to perceive the unstressed and reduced syllables and this often leads to serious comprehension problems as these learners are unable to recognise words which they may easily recognise on the printed page. These difficulties are so serious for certain individuals that some French authors have posited the existence of a "stress deafness" concerning some languages such as English, where stress plays a defining role (Dupoux and Peperkamp 1999, Dupoux, Peperkamp and Sebastian-Galles 2001, Peperkamp and Dupoux 2002). Although researchers have not always agreed on the relative importance of the acoustic cues F0, amplitude, duration and formant structure in English, the importance of F0 in English is undeniable - indeed it is the importance of perceived pitch which led Bolinger (1958) to call stress in English "pitch prominence". As we shall see, French does not have lexical stress, and the role of F0 is less important; moreover it does seem clear that there is a difference in the way prominence is perceived by French and English natives (Frost 2011).

The importance of the F0 curve for English, comparably more so than in French in terms of perception of prominent syllables and for other information carried by the intonation curve, may account to some degree for the apparent "stress deafness" of certain French learners of English, but segmental features also have their role to play. As Jenkins (2000: 147) points out, the weak/strong syllable alternation is a characteristic feature of all varieties of English. She also says it is "unteachable", an assertion which she fails to illustrate with any research and with which we disagree strongly. On the contrary, a failure to teach adequately the production and perception of weak forms in 
France is, we believe, one of the main reasons for the difficulties of many French learners when it comes to speaking and understanding English.

Although French does not have word stress, there is relative prominence, but to a lesser degree than in English (Rossi 1979) and that prominence is evident at the end of prosodic units (Dahan and Bernard 1996), be they shorter "stress groups" (Di Cristo 1998) or longer "accentual phrases" (Jun and Fougeron 1995). This contrasts with English, which has been characterised as a "leader-timed" language, whereas French is "trailer-timed" (Wenk and Wioland 1982: 204). A further difference between English and French is that French clearly marks this group-final syllable with an increased duration - this is not to say that amplitude and F0 are not factors, but syllablelengthening is the most salient feature (Benguerel 1973, Di Cristo 1998, LacheretDujour and Beaugendre 1999: 41, Jun and Fougeron 2000, Astesano 2001). Of course, this may be largely explained by purely articulatory factors, i.e. the fact that this final syllable often corresponds to the end of a breath group, so there is less acoustic energy available for the realisation of the final syllable, as Lindblom puts it "Granted the assumption of the energy per syllable being constant final lengthening of segments becomes a consequence of the intensity being lower in the final part of the basic phrase contour" (Lindblom 1968: 10). Indeed, many studies have shown this phenomenon to be present in English and in other languages (see Turk and Hufnagel 2007 for a discussion of phrase-final lengthening).

Perhaps the most important difference between French and English, one which is linked to the previous points, is that of the overall rhythmical or metrical structure. The concept of isochrony (Pike 1945) has been questioned by many authors (see Bertinetto 1989 for an overview) and clearly as a purely binary paradigm, it is not an accurate description of how metrical patterns actually behave in reality; to say that "English is stress-timed" and "French is syllable-timed" is not borne out by the facts, at least not once an utterance goes beyond isolated words or perhaps tone units: pauses, errors, repetitions and other features of real discourse make isochrony more of an abstract concept than an accurate term for describing real language. However, as a concept for raising the awareness of learners and teachers to different metrical structures, it can be useful to discuss isochrony in lessons and teacher-training workshops.

\section{Why put prosody first in teaching?}

We are not alone, however, in calling for more attention to prosody in language teaching. Its importance has been widely written about over the last two decades in particular, for example in regard to fluency (Wennerstom 2000), comprehensibility (Odlin 1989; Anderson-Hsieh et al. 1992; McQueen et Cutler 1997; Murphy 2004; Murphy et Kandil 2004; Rasier and Hiligsmann 2007) and for structuring language (Philippe 2013). In addition, numerous authors have called for more attention to be paid to prosody in teaching (Gilbert 2008; Kjellin 1999a, Kjellin 1999b; Levey 2001; Baker and Murphy 2011; Munro and Derwing 2011; Saito 2012).

In summary then, the reasons for needing to address oral skills in EAP/ESP in France are many: the disparate nature of ESP/EAP in French tertiary education, the vicious circle of poor teacher training feeding into poor teaching with regard to pronunciation 
and particularly prosody and the vast differences between the prosody of English and French. These factors have cumulated to produce a situation where many French learners of English simply cannot understand spoken English and struggle to express themselves when speaking English. In the next part, we shall see some of the solutions that we have been putting into place over the last two years and will continue to implement over the next four years of the Innovalangues project, especially (but not only) regarding English and prosody.

\section{The Innovalangues project}

The Innovalangues project ${ }^{4}$ is a six-year project which started on June 14, 2012 and coordinated by Monica Masperi at Université Stendhal (Grenoble 3) and is composed of a large team of teachers, researchers, resource developers and administrative staff, some of whom are employed full-time and some part-time to work on the project. Innovalangues has substantial funding from the ANR (Agence Nationale pour la Recherche) - the research funding body of the French Ministry of Higher Education and Research - as part of the IDEFI programme ${ }^{5}$. Its primary mission is to develop initiatives which will help to bring the levels of LSP/LAP learners to a certified B2 level as defined by the CEFRL over the three years of their university career. Initially, the target learners are in the Universities of Grenoble, but the project will eventually target learners nationally and internationally. The project has several national and international partners, including Mons University, Belgium, The Réseau Européen des Associations de Langues (REAL), Lingua e nuova didattica (LEND), Italy and the private company Totemis.

As we mentioned in the introduction, it is obligatory in France to study a foreign language at university for all students; by far the largest demand is for English, but the Maison des Langues et des Cultures at Université Stendhal offers courses in many languages (including Polish) ${ }^{6}$. The languages concerned by Innovalangues are initially English and Italian, followed by Spanish, German, Chinese and Japanese.

Blended learning is at the heart of the project, with the development of a digital ecosystem, built around a CLMS (Content and Learning Management System), Claroline Connect ${ }^{7}$. Innovalangues has a team of full-time IT developers who are working with the Claroline developers to produce a set of plug-ins conceived by the various teams on the Innovalangues project, according to their specific demands and in accordance with the principles of agile development. The project currently comprises seven teams all of which have been tasked with providing innovative approaches to the problem of helping the students in the learning situations described above to achieve B2 level (their names are often acronyms in French which we have chosen to paraphrase / translate):

\footnotetext{
4 http://lansad.u-grenoble3.fr/version-francaise/a-1-affiche/le-projet-innova-langues-laureat-de-lappel-aprojets-national-idefi-128927.kjsp

5 « Initiatives d'Excellence en Formations Innovantes ». http://www.agence-nationale-recherche.fr/investissementsdavenir/AAP-IDEFI-2011.html

${ }^{6} \mathrm{http}: / /$ lansad.u-grenoble3.fr/

${ }^{7} \mathrm{http}: / / \mathrm{www}$. claroline.net/
} 
- $\quad$ THEMPPO (oral production and prosody)

- $\quad \boldsymbol{C O C A}$ (oral comprehension - "exerciser" and learning support)

- $\quad$ CASSIS (application design in support of social interaction)

- Parcours (conception of model learning paths)

- ColOr (collaborative oral expression practice)

- $\quad \boldsymbol{S E L F}$ (formative and diagnostic assessments for languages)

- $\quad \boldsymbol{G A M E R}$ (serious gaming techniques applied to language learning)

- Approches créatives (creative approaches for languages, e.g. dance, music, drama, games-to-learn, etc.)

\section{The THEMPPO team}

The team which the present article is most concerned by is THEMPPO (Thématique Prosodie et Production Orale). Along with SELF, this is one of the largest teams in the project. It started in January 2013. The members of the group are all professional English teachers and researchers and all have interests outside their professional life in areas which are pertinent to this domain, namely music, song, theatre, poetry and dance. The THEMPPO team is split into two working groups, who each come at the question of oral production from a different angle: the "prosody" group is concerned primarily with rhythm, stress and intonation and the "voice" group works on the more physical aspects of oral production using voice training techniques, etc. adapted from their background in acting. The team as it is currently organised has a coordinator for the whole group (Francis Picavet) and a coordinator for the development of English-specific tools and resources (Dan Frost). As more languages are brought into the project, each language will have a coordinator to oversee the development of resources in that particular language.

THEMPPO's approach to the problems laid out in the first part of this article is threefold: firstly, a series of teacher-training seminars, secondly, the development of teaching resources for use on within the digital eco-system as part of a blended learning programme and thirdly, an action-research programme.

The teacher-training seminars started almost as soon as the THEMPPO team was formed and they serve two purposes: they are a useful way of disseminating information about the project and recruiting new members for the various teams, but essentially, they are a powerful way of breaking the vicious circle described above. As the proverb states, "give a man a fish and you feed him for a day; teach a man to fish and you feed him for a lifetime". Each of the workshops has about 20 participants and there are at least six per year, so by sharing our ideas with this many local teachers, we hope to be able to influence the learning of a great number of students for decades to come. The titles of the seminars in 2013-14 are as follows:

- The "prosody" group:

○ Raising awareness to rhythm

- From rhythm to meaning

○ Musicality in language learning

○ From melody to the gamut of sounds 
- $\quad$ The "voice" group:

- Freeing the body, liberating the voice

$\circ$ Sound and feeling

From the titles of the workshops, all in English for the moment, it is clear that the focus of both groups is not initially on the sounds of the language. It is our belief that when pronunciation is actually taught (which we believe is not often enough in LSP/LAP), the focus is all too often on segmentals, rather than on prosody. Yet if we are to concentrate on the real needs of our learners in the area of oral language, those needs are comprehensibility and comprehension. The numerous studies cited in part 3 above and our own experience over decades of teaching and researching language learning France have convinced us that prosody is the area which must be focused on. This is why the motto of the "prosody" group is "put prosody first"; the workshops provide theory to explain to teachers why this is the case and practical and fun ways of working on prosody with learners. The links between music, language and the brain have been researched extensively (Patel 2008), and although speech and song are of course different, the parallels between prosody and music are evident and music is a very important pedagogical tool in our work. At the production level prosody, especially stress, is extremely iconic (Pennington 1996: 137), i.e. acoustic effort coincides with meaning, a correspondence which is rare elsewhere in the sign / meaning relationship in human language. In order to achieve real changes in the production of prosody, which is an extremely iconic and physical part of human speech production, it is clear to us that this work must be preceded and reinforced by work on the body and on the articulators, hence the very physical approach of the "voice" group".

The second approach is the development of tools for use in the blended learning programme which is the backbone of Innovalangues. Two plugins for the CLMS are currently under development and are at the prototype stage as we write this article, namely a video active comparative tool (VAC) and a metronome. The video active comparative tool is an integral part of the methods employed by both the "prosody" and the "voice" groups. The audio active comparative (AAC) approach favoured by the behaviourist school which saw the spread of language laboratories from the sixties for over thirty years (Ginet 1997) is certainly not the panacea to all the problems of language learning, but repetition and critical listening are particularly useful for prosody (Frost 2004, 2008). The addition of video, which would have been not only technically impossible ten years ago, but would also have been very disconcerting for learners, is now something which is in keeping with the practices of many of the Youtube generation of Internet natives. As the realisation of prosodic features is such a physical phenomenon and is very often accompanied by gestures, the possibility for learners to record video and sound is an extremely useful addition to the traditional AAC approach. The VAC tool will also be essential for the activities developed by the "voice" group, as the learners must become aware of and modify their posture, breathing and the movement of their own bodies and articulators. The metronome is a tool which has been used by language teachers before (Beaucamp, 2008), but its use has been proven to be highly effective with the target learners (Picavet et al. 2012, 2013) and systematized by the THEMPPO team and will be used with the VAC tool. 
The third tool which is currently at the prototype stage is not actually an IT tool, but is part of the blended learning programme, both for use in the digital eco-system and in the classroom: a set of descriptors for describing and measuring the production of various prosody features, such as the placement of word stress and tonic stress, reductions, connected speech phenomena, etc. Very much work in progress (hence the lack of its inclusion as an appendix to this article), this tool is intended for use both by learners as part of their self-assessment and by teachers as a diagnostic tool and as part of a formative assessment programme. It is inspired by the work of the CEFRL, but as the CEFRL is not language-specific and is concerned with fluency and "can-do" descriptors, the section on "phonological control" is vague to say the least, stating merely "Has acquired a clear, natural, pronunciation and intonation" at B2 level (Council of Europe 2001: 117). The prosody descriptors, currently undergoing pilot tests in an attempt to peg them to the CEFRL levels are an attempt, as was the CEFRL itself, to raise awareness to the issues it highlights rather than to give a grade or a mark as such.

The final approach adopted by the THEMPPO team as by most of the other teams in Innovalangues, is that of action-research. According to the cyclical process of actionresearch, as new approaches are developed by the two groups in the THEMPPO team, they are piloted and then tested on the learners for whom they were developed, any necessary modifications are made to the tools and/or contents and/or learning paths and then the process is repeated. A more accurate term, at least insofar as the plugins for the CLMS are concerned, would be action-development ("recherche-développement", Guichon 2007), as the results of the process of action-research feed into the process of agile development of the plugins. The results of the testing of the resources developed by THEMPPO and the other teams, will of course be shared with other members of the teaching and research communities interested in our work both within France and internationally.

\section{Conclusions}

The project is still only in its second year and is set to run until 2018 so there are bound to be changes to the structure of the project, the way the teams are organised and the work they produce. For the moment, English and Italian are the only two languages represented in the project, but the approaches developed for these languages will be transferred to the other languages mentioned above and new approaches will be developed according to the needs of those languages. It is true that the combination of teacher-training, resource development and action-research are certainly not, in themselves, innovative. However, the unique combination of the teams which make up the Innovalangues project, along with the tools, content and learning paths being developed to make up the digital ecosystem certainly are. The THEMPPO team's approach, i.e. putting prosody first, is one of which we are not aware elsewhere in France or indeed, at least on a comparable scale, elsewhere in the language teaching literature. THEMPPO hopes therefore to be able to chip away slightly at the vicious circle outlined at the beginning of this article. 


\section{References}

Anderson-Hsieh, J. 1994. "Interpreting Visual Feedback on Suprasegmentals in Computer Assisted Pronunciation Instruction », Calico Journal, 11(4): 5-16.

Astésano, C. 2001. Rythme et accentuation en français. Invariance et variabilité stylistique. Paris: Editions L'Harmattan, Collection Langue et Parole.

Bailey, T., K. Plunket, and E. Scarpa,. 1999. "A Cross-Linguistic Study in Learning Prosodic Rhythms: Rules, Constraints and Similarities", Language and Speech, 42, (1): $1-38$.

Beaucamp, J. 2008. «Enseigner une langue vivante étrangère à l'école (cycle 3) : opportunité d'un début de réflexion métaphonologique et métalinguistique ». Les Cahiers de l'Acedle, 3: 15-39.

Benguerel, A-P. 1973. Corrélats physiologiques de l'accent en français. Phonetica 27: 21-35.

Bertinetto, P.M. 1989. "Reflections on the dichotomy 'stress' vs. "syllable-timing"". Revue de Phonétique Appliquée 91-93, 99-130.

Baker, A. and J. Murphy. 2011. "Knowledge Base of Pronunciation Teaching: Staking Out the Territory", TESL Canada Journal / Revue TESL du CANADA: 29-50.

Bolinger, D. 1958. "A Theory of Pitch Accent in English”, Word, 14: 109-149.

Brossard, J. (1995) Enseigner la phonétique anglaise. Paris : Bordas.

Campione, E., and Véronis, J. 1998. "A statistical study of pitch target points in five languages", 5th International Conference on Spoken Language Processing (ICSLP'98), Sidney: 1391-1394.

Council of Europe. 2001. A Common European Framework of Reference for learning, teaching and assessment. Cambridge: Cambridge University Press.

Dahan, D. and J-M. Bernard. 1996. "Interspeaker Variability in Emphatic Accent Production in French", Language and Speech, 39(4): 341-374.

Delattre, P. 1965. Comparing the Phonetic Features of English, French, German and Spanish: An Interim report. Heidelberg: Julius Groos Verlag.

Di Cristo, A. 1998. "Intonation in French", in D. Hirst and A. Di Cristo, (eds). Intonation Systems: A Survey of Twenty Languages. Cambridge: Cambridge University Press: 3-45.

Dupoux, E, S. Peperkamp and N. Sebastian-Galles. 2001. A robust method to study stress-deafness. Journal of the Acoustical Society of America 110(3.1): 1606-1618.

Dupoux, E. and S. Peperkamp. 1999. Fossil markers of language development: Phonological 'deafness' in adult speech processing. In Laks, B. and J. Durand, (eds), Cognitive phonology. Oxford: Oxford University Press: 168-190.

Frost, D. 2004. «L'enseignement de l'accent lexical dans le secteur LANSAD : quelques notes sur une expérience de recherche-action en auto-apprentissage », ASP 43-44: 99-106.

Frost, D. 2008. « The Stress Site la conception d'un parcours multimédia pour un travail en autonomie sur l'accentuation des mots » ASP 53-54: 111-127.

Frost, D. 2010. Stress cues in English and French: a perceptual study. Journal of the International Phonetic Association, 41(01): 67-84.

Gilbert, J. 2008. Teaching Pronunciation Using the Prosody Pyramid. Cambridge: Cambridge University Press. 
Gilbert, J. 2010. "Pronunciation As Orphan: What Can Be Done?", As We Speak (TESOL Newsletter) 7(2).

Ginet, A. (dir.) et al. 1997. Du laboratoire de langues à la salle de cours multi-médias. Paris: Nathan.

Goulier, F. 2007. Les outils du Conseil de l'Europe en classe de langue. Cadre européen commun et Portfolios. Paris, Strasbourg : Conseil de l'Europe, Didier.

Guichon, N. 2007. « Recherche-développement et didactique des langues », Les Cahiers de l'ACEDLE 4: 37-54.

Henderson, A., D. Frost, E.Tergujeff, A. Kautzsch, D. Murphy, Kirkova-A. Naskova, E. Waniek-Klimczak, D.

Levey, U. Cunningham, and L. Curnick, Lesley. 2012. "The English Teaching in Europe Survey: Selected Results. Research in Language 10(1): 5-28. DOI: 10.2478/v10015011-0047-4

Hirst, D. and A. Di Cristo (Eds). 1998. Intonation Systems: A Survey of Twenty Languages. Cambridge: Cambridge University Press.

Jenkins, Jennifer. 2000. The phonology of English as an international language. Oxford: Oxford University Press.

Jun, S. and C. Fougeron. 1995. "The accentual phrase and the prosodic structure of French". 13th International Congress of Phonetic Sciences (ICPhS 12), vol. 2: 722725.

Kjellin, O. 1999a. "Accent Addition: Prosody and Perception Facilitates Second Language Learning”. In O. Fujimura, B. D. Joseph, and B. Palek (Eds), Proceedings of $L P^{\prime} 98$ (Linguistics and Phonetics Conference) at Ohio State University, Columbus, Ohio, September 1998 (Vol. 2), Prague: The Karolinum Press: 373-398.

Kjellin, O. 1999b. "Five Cornerstones for Second-Language Acquisition - the Neurophysiological Opportunist's Way”. Unpublished: 1-9.

Lacheret-Dujour, A. and F. Beaugendre. 1999. La prosodie du français. Paris: CNRS.

Levey, D. 2001. "Stressing Intonation", in Harris, T., I. Roldan, I. Sanz, and M. Torreblanco, (eds). ELT2000: Thinking Back, Looking Forward. Granada: Greta: 3545.

Lindblom, B. 1968. "Temporal organization of syllable production". Speech Transmission Laboratory Quarterly Progress, Royal Institute of Technology, Stockholm, Sweden, 2-3: 1-6.

McQueen, J. and A. Cutler. 1997. "Cogntive Processes in Speech Perception", in W. Hardcastle and J. Laver, (eds), The Handbook of Phonetic Sciences. Oxford: Blackwell: 556-585.

Major, R. C. 2008. "Transfer in second language phonology. A review", in J. Hansen Edwards and M. Zampini, (eds) Phonology and Second Language Acquisition. Amsterdam: John Benjamins: 63-94.

Martin, P. 2013. «La structure prosodique opère-t-elle avant ou après la syntaxe?». TIPA. Travaux interdisciplinaires sur la parole et le langage, 29.

Munro, M.J. and T.M. Derwing, (2011). "The foundations of accent and intelligibility in pronunciation research". Language Teaching 44 (3): 316 - 327.

Murphy, J. 2004. "Attending to Word Stress while learning new vocabulary", English for Specific Puposes, 23: 67-83. 
Murphy, John et Kandil, Magdi. 2004. "Word-level stress patterns in the academic word list", System, 32: 61-74.

Odlin, T. 1989. Language Transfer. Cross-Linguistic influence in Language Learning. Cambridge University Press: Cambridge.

Patel, A. 2008. Music, Language and the Brain. Oxford: Oxford University Press.

Pennington, M. 1996. Phonology in English Language Teaching. London: Longman.

Peperkamp, S. and E. Dupoux. 2002. "A typological study of stress deafness", in Gussenhoven, C. and Warner, N. (eds). 2000. Laboratory Phonology 7. Berlin: Mouton de Gruyter: 203-240.

Picavet, F., V. Aubergé. and S. Rossato. 2012. "Can a guided rhythmic approach contribute to the oral performance of learners of L2 English? A case study". Methodological Perspective on Second Language Prosody. M.G. Busà, A. Stella, (eds). Padua, Italy: Cooperativa Libraria Editrice Università di Padova (CLEUP): 73 77.

Picavet, F., V. Aubergé. and S. Rossato. 2013. « Production orale en anglais : travailler en rythme, produire du sens et être compris ». Les Langues Modernes, 4: 104-114.

Picavet, F. and D. Frost. 2014. « Le lot THEMPPO dans le projet Innovalangues : recherche-action en prosodie et en production orale ». LEND - Lingua e Nuova Didattica, 1: 29-35.

Pike, K. 1945. The Intonation of American English. Ann Arbor: University of Michigan Press.

Rasier, L. and P. Hiligsmann. 2007 « Prosodic transfer from L1 to L2. Theoretical and methodological issues », Nouveaux Cahiers de linguistique française, 28: 41-46.

Rossi, M. 1979. «Le français, langue sans accent ? », in I. Fónagy and P. Léon (eds) L'accent en français contemporain. Montréal / Paris / Bruxelles: Didier: 93-106.

Saito, K. 2012. "Effects of instruction on L2 pronunciation development: A synthesis of 15 quasi-experimental intervention studies". TESOL Quarterly, 46(4): 842-854.

Scarcella, R. and R. Oxford. 1994. "Second Language Pronunciation: State Of The Art In Instruction", System 22(2): 221-230.

Taillefer, G. 2002. «L'anglais dans les formations spécialisées à 1'Université : un cheveu sur la soupe? Peut-on rendre le plat plus appétissant? », ASP 37-38: 155-172.

Taillefer, G. 2007. « Le défi culturel de la mise en œuvre du Cadre européen commun de référence pour les langues : implications pour l'enseignement supérieur français ». Les Cahiers de l'APLIUT 16(2): 33-49.

Turk, A. and S. Hufnagel. 2007. "Multiple targets of phrase-final lengthening in American English words", Journal of Phonetics 35(4): 445-472.

Wenk, B.J. and F. Wioland. 1982. "Is French really syllable-timed? Journal of Phonetics 10: 193-216.

Wennerstrom, A. 2000. "The Role of Intonation in Second Language Fluency", in H. Riggenbach (ed) Perspectives on Fluency. Ann Arbor, MI: University of Michigan Press: 102-127.

Vaissière, J. 2002. Cross-Linguistic Prosodic Transcription: French versus English. Problems and Methods in Experimental Phonetics, in honour of the 70th anniversary of Prof. L.V. Bondarko,. N. B. Volslkaya, N. D. Svetozarova and P. A. Skrelin. St. Petersburg: 147-164. 